821.163.41.08-13 Петровић Његош П. Р. II 811.163.41'282.3(497.16) https://doi.org/10.18485/sj.2019.24.1.35

ДРАГАНА М. РАТКОВИТ ${ }^{*}$

Институт за српски језик САНУ

Београд
Оригинални научни рад Примљен: 11. 09. 2018. Прихваћен: 15. 01. 2019.

\title{
ДИЈАЛЕКАТСКЕ ПОЈАВЕ У ВЕЗИ С ЈАТОМ У КРИТИЧКОМ ИЗДАЬУ „ГОРСКОГ ВИЈЕНЦА” РАДМИЛА МАРОЈЕВИЋА
}

У раду се разматрају дијалекатске појаве у вези с јатом у „Горском вијенцу” у оквиру теме о фонетским дијалектизмима у Његошевом спеву. Дате појаве се разматрају са аспекта њиховог књижевнојезичког статуса, распрострањености у ијекавским народним говорима и функције у песничком тексту. Грађу чини критичко издање „Горског вијенца” Радмила Маројевића из 2005. г.

Кључне речи: Петар II Петровић Његош, „Горски вијенац”, јат, дијалектизми.

0. Рефлекс дугог јата у „Горском вијенцу” има двосложни, књижевни рефлекс или једносложни (дифтоншки), дијалекатски, ије-изговор, условљен метричком структуром стиха, при чему је овај други различито штампан и интерпретиран. У издањима М. Решетара и потоњих приређивача (нпр. Решетар 1890; Решетар ${ }^{10} 1940$; Драгићевић 1959) он је штампан са апострофом (св 'јет, ив 'јет итд.) јер је схваћен као двосложни рефлекс дугог јата редукован из метричких потреба. У критичком издању „Горског вијенца” Р. Маројевић

*Dragana.Ratkovic@isj.sanu.ac.rs

** Рад је настао у оквиру пројекта 178009 Лингвистичка истраживана савременог сриског књижевног језика и израда Речника српскохрватског књижевног и народног језика САНУ, који финансира Министарство просвете и науке Републике Србије. 
га обележава графемом ъ, онако како је обележен у првом, бечком издању (Његош 1847). Овом графемом се у наведеном критичком издању обележава и рефлекс кратког јата после сугласника $c$ (уп. Маројевић 2005: 12). Такво двојство рефлекса дугог јата карактерише староцрногорски, црмнички говор (Милетић 1940: 239-240), али и говоре централне и северне Херцеговине (Peco 1989: 114-115).

1. ЈЕДНОСЛОЖНИ РЕФЛЕКС ДУГОГ ЈАТА. - Једносложни рефлекс дугог јата: $\bar{\varpi}>$ [굴] у „Горском вијенцу” налазимо код именица, придева, прилога и глагола.

1.1. Примери за именичке форме су следећи: гњъздо, вънаи, тъло, свъm и иุвът:

ђе вираху ка миши из гњъзда. [ГВ 1540];

жалије му снахин вънач и било [ГВ 1299];

рани твло и огњем електризма, [ГВ 2326]

Тъло стење под силом душевном - [ГВ 2511];

Свъm је овај тиран тиранину [ГВ 2499];

пожњеш ми га у извъту и младости; [ГВ 981].

Све ове именице имају облике и са књижевним рефлексом дугог јата:

СЪм Азије, ђе им је гъијездо, [ГВ 19]

Него своје размеће гъијездо [ГВ 122]

О гюијездо јуначке свободе, [ГВ 710]

Чево равно, гњијездо јуначко [ГВ 1733];

тада она вијенаи расплете, [ГВ 1289]

или имах китнога вијенца [ГВ 979]

под вијенцем гори Даница, [ГВ 1864];

ма тијела како ватра жива! [ГВ 1879]

иако ми јошт тијело душу [ГВ 2256]

у њ ратује душа са тијелом, [ГВ 2502]

Да кад главу раздробиш тијелу, [ГВ 47]

Колеба се душа у тијелу; [ГВ 2512]

Мален свијет за адова жвала, [ГВ 27],

у ад ми се свијет претворио, [ГВ 41],

у свијет га јошт није таквога [ГВ 177],

да га свијет мори пријекором, [ГВ 1052],

није свијет оно што мишљасте: [ГВ 1136],

свијет ми се око главе врти! [ГВ 1280],

Бјеху куће на свијет дивота, [ГВ 1424],

и тиска[ј] их у свијет бијели [ГВ 1453],

Мишљаху ли у свијет за кога? [ГВ 1502],

а обрну свијет наопако [ГВ 2027],

а свијет га оваквога нема! [ГВ 2092], 


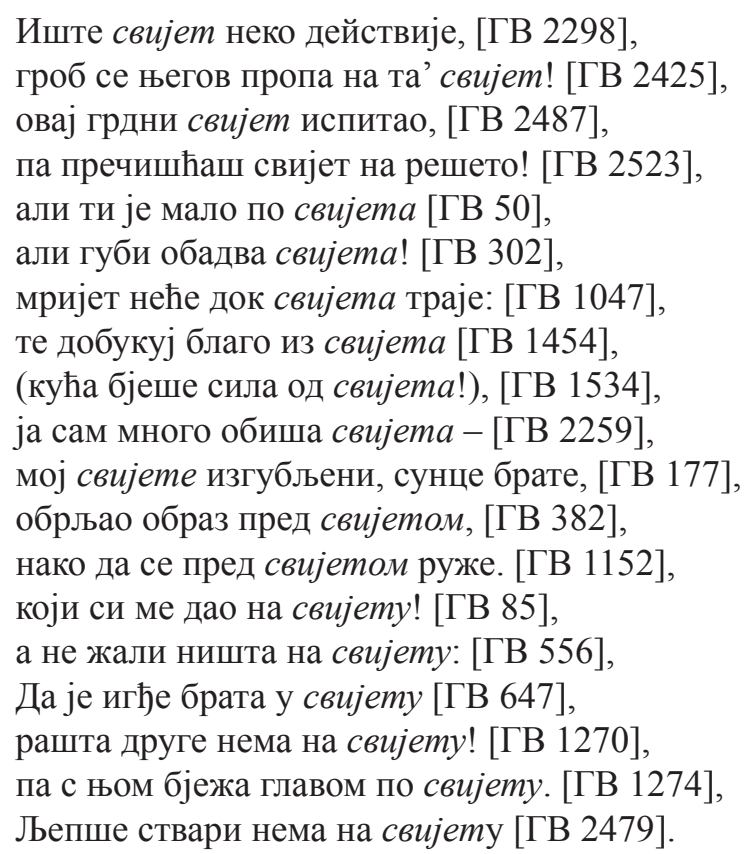

У критичком издању Р. Маројевић ијекавске облике лексеме гнездо интерпретира са њ: [гњијездо] и [гњ 미ездо] наводећи као цитат своје раније тумачење да мекоћа тог сугласника у именици гњијездо „није настала јекавским јотовањем (ни у једном облику ријечи није било фонетских услова за то): дијалекатска промјена $g n>g n ́$ испред вокала $i$ само понавља промјену која је била карактеристична већ у прасловенском (тиме се објашњава мекоћа

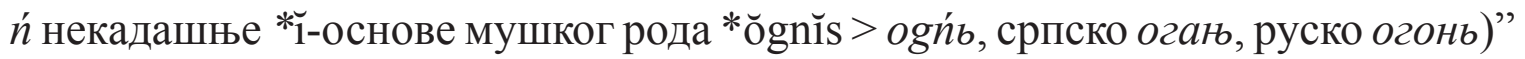
(Маројевић 1997: 52-53; Маројевић 2005: 806).

Облик гнијездо Његош не употребљава. Т. Маретић каже да „iza $g$ prelazi $n$ katkad u ń” наводећи као пример Срем, где „,mjesto gnizdo (tj. gnijezdo, gnezdo) govore gnjizdo" (Maretić ${ }^{3} 1963$ [1899]: 105). У Вуковом Рјечнику (Караџић ${ }^{4} 1935$ [1852]) стандардна је само варијанта са н: гнијѐздо, гнијѐжђе̄ње, гнијѐздити (се), док се облик са њ бележи само у форми гњи́здо са квалификатором „у Сријему” и упућује на облик гнијѐздо. У Речнику САНУ (РСАНУ 1959-2017) гњездо, гњиздо и гњијездо квалификују се као дијалекатски облици именице гне́здо ијек. гнијѐздо.

У дијалектолошкој литератури о ијекавским говорима налазимо облике наведене лексеме са $t$ и њ у говорима оба типа. У говору Црмнице чује се: „гнйезздо (обично гњйезздо, гњёздо)” (Милетић 1940: 366). Исто тако се и у говору Бјелопавлића „Мијешају групе гн и гъ у ријечи гнијездо, па у овом говору имамо гњиие́здо и гниие́здо" (Ћупић 1977: 57). И у говору источне Херцеговине „, иза г прелази у њ као и [у] другим говорима нашим гњиједзо [гњијездо - Д. Р.]” (Вушовић 1930: 114). 
1.2. Дијалекатске облике са једносложним рефлексом дугог јата код придева налазимо у облицима женског рода лексема снежан и бео:

снъжна гривна ситна бисера, [ГВ 1868];

Бъле власе низ плећи просуо, [ГВ 587]

бъла брада вије до појаса, [ГВ 588]

бъле руке - крила лабуда, [ГВ 1870]

око бъле куле нанијели [ГВ 2769].

Књижевне облике, са двосложним рефлексом, налазимо код придева бео:

што л бијела сунцу на зјеницу! [ГВ 641]

на бијела хата ка на вилу - [ГВ 238569]

играју се на бијела јата [ГВ 2635]

у лађама пут бијела Скадра, [ГВ 2698]

Љепша му је од виле бијеле, [ГВ 1265]

као у нас Бијеле неђеље [ГВ 1437]

И у боју код бијеле куле [ГВ 2790]

и тиска[ј] их у свијет бијели [ГВ 1453]

по му лица црно, по - бијело. [ГВ 816]

млијеко је да рече бијело. [ГВ 1664]

пресули их бијелом шеницом [ГВ 2441].

1.3. Од прилошких дијалекатских облика бележимо само послв, који се налази у једном примеру:

Послъ тридест-четрдест друга̂ причај [ГВ -2387],

насупрот бројним одговарајућим облицима са књижевним рефлексом дугог јата:

ти издао пријед и послијед, [ГВ 381]
па послијед поче ђетињити - [ГВ 1640]
Кад послијед - све оно излиња [ГВ 1661]
Па послијед што се од вас ради? [ГВ 2140].

Облике са секвенцама $с л \mathfrak{z}$ и снъ, који су у критичком издању „Горског вијенца" интерпретирани као облици са једносложним рефлексом дугог јата (послв, снъжна), Д. Вушовић тумачи као облике са кратким јатом и извршеним јекавским јотовањем (посље, съежна). Као потврду, Вушовић наводи такав облик у „црногорском дијалекту” (Вушовић 1930: 102-103). Реч посль Р. Маројевић интерпретира као облик са једносложним ије-рефлексом дугог

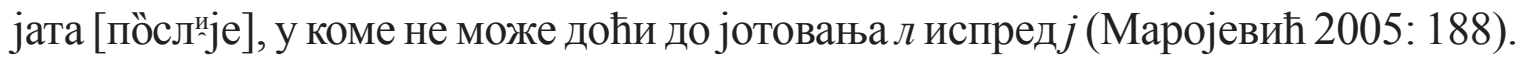
У основи Вушовићеве интерпретације, по Р. Маројевићу, лежи акустичка варка - чује се посљь, али се изговара [пӧслије], облик са редукованом и неслоговном првом компонентом дифтоншког алофона (ํㅜㄹ) (Маројевић 2005: 818).

1.4. Глаголске облике бележимо у презенту, аористу и радном глаголском придеву. Примере за презент налазимо у три стиха: 
да ми свъ тли круна Лазарева [ГВ 784];

а мени се ка у зарок стъъц̧а, [ГВ 1379];

не пушта се да је зло побъди: [ГВ 2313],

а за аорист односно радни глаголски придев у једном стиху:

ту сагръии и Богу и Пророку [ГВ 1814];

Мало људство, што си засльпило [ГВ 888].

Алтернативне књижевне облике ових глагола у „Горском вијенцу” не налазимо. Бележимо само облике са књижевним рефлексом дугог јата код лексема из одговарајућих творбеног гнезда: свијетли, у одређеном виду, гријех, слијеп и слијепаų:

сва свијетла кола у простору, [ГВ 745]

Боже драги, свијетла празника: [ГВ 2632]

над образом свијетла језера! [ГВ 2638]

како росне свијетле капљице [ГВ 996]

ко кођ паше свијетло оружје, [ГВ 669]

испод твога трона свијетлога [ГВ 747];

препунисте мјешину гријеха! [ГВ 1142];

па сам слијеп доша међу вама [ГВ 2249]

Ти нијеси слијеп игумане [ГВ 2361]

будале су с очима слијепе, [ГВ 2363]

и сл[иј]епи игуман Стефан с бројаницама у руке. [ГВ -2218];

Пјесна добра спава у слијепиа, [ГВ 2369]

а слијепиу очи не сметају, [ГВ 2377].

2. РЕФЛЕКС Е ПОСЛЕ Р И КРАТКОГ ЈАТА. - У „ГорсКом вијенцу" кратко $z$ после гласа $p$ има рефлекс $e$. Примере налазимо код именичких облика: сагрешења, грехови, грехота, времена, прилога малопред и глагола прегорети и изгорети:

за њихова смртна сагрешења: [ГВ 199];

поп грешника за грехове пита [ГВ 807];

грехота је о том и мислити; [ГВ 1138]

грехота је да их поткидамо. [ГВ 1885]

не прими ми Боже за грехоту: [ГВ 2450];

и дављаху кише и времена, [ГВ 1470];

ка малопред што гордо иђаше, [ГВ 241]

ка малопред што гордо иђаше [ГВ 245];

Па све могах с јадом прегорети, [ГВ 1281]

„Бјеж народе е изгоре кућа!” [ГВ 1564]

куће турске огњем изгоресмо [ГВ 2604]. 
У Вуковом Рјечнику налазимо облике: грјехо̀та, изго̀рјети и прего̀рјети. У Речнику САНУ књижевнима се сматрају облици: грехотта и изгорјети, док облици грјехота и изгорети имају ознаку „некњ. ијек.”. Као стандардна ијекавска форма наводи се мӑлопријед.

Његошева употреба одговара стању у ијекавским говорима како старијег тако и новијег типа. У црмничком говору: „иза $p$ прелази кратко $z$ без изузетка у е" (Милетић 1940: 247). Исто је у средњокатунским и љешанским говорима. „Изузеци су стӓрјешина и старјешиิнство (забележено у Парцима, Љешанска Нахија)" (Пешикан 1965: 104). Облике код Његоша Р. Маројевић објашњава као резултат стања у развоју најпрогресивнијих ијекавских говора (Маројевић 2005: 808-809).

3. ЕКАВИЗМИ. - У Његошевом језику налазимо још неке е-рефлексе јата: у именицама колевка, леб, млеко, време и прилозима досле, овде и онде (на):

из колевке Белонине и на земљи показаше [ГВ П 4];

да одеру кору леба суха. [ГВ 1414]

Ту не бјеше јела изван леба, [ГВ 1667];

који га је млеком одранио - [ГВ 637];

време земно и људбина људска - [ГВ 2290];

па живите као досле што сте. [ГВ 1103];

овде људско запире познање). [ГВ 615]

од некрсти овде заудара. [ГВ 1252]

не смије се овде право зборит; [ГВ 1494]

видите ли овде у Котору [ГВ ГВ 1675]

сврх мене се сви овде куните - [ГВ 2180]

Нема, бабо, овде духовника, [ГВ 2191]

имам овде десетак ђачади, [ГВ 2542];

онде нека и плодом почине [ГВ 613]

Ондена се мало не покласмо - [ГВ 1359].

Притом, именици колевка и прилошким облицима са секвенцом де алтернирају облици са двосложним рефлексом односно секвенцом $\partial z$, овђе(на) и онђе:

а одњиха једна колијевка, [ГВ 2641]

колијевке какве би требале [ГВ 2286];

у њих данас овђе видијесмо? [ГВ 113]

Без момчади ове те су овђе [ГВ 126]

Погибосмо овђе чекајући: [ГВ 322]

сто пута сам овђена с ъдио [ГВ 1761];

Има онђе и Црногораца [ГВ 1761]; 
Облик лёб, без иницијалног $x$, у Вуковом Рјечнику се без квалификатора упућује на хлёб при чему се оба облика интерпретирају као екавизми. У Речнику САНУ именица лёб се квалификује као дијалектизам од хлеб. Р. Маројевић у критичком издању лёб интерпретира као народски екавски облик (Маројевић 2005: 122, 137). Д. Вушовић каже да се врло често чује у Црној Гори (Вушовић 1930: 104).

Именице мле́ко и вре́ме у Вуковом Рјечнику и Речнику САНУ су описане као екавизми. У критичком издању Р. Маројевић је именице време и млеко квалификује као црквенославенизме (Маројевић 2005: $74,183,811,813$ ). Облик млеко јавља се и у неким народним ијекавским говорима (уп. Станић 1974: 76). У тим описима он се интерпретира као екавизам, и то као резултат утицаја екавског говора путем књижевног језика и мешања становништва.

За Т. Маретића је особина ,јужног говора” двојака замена $z$ у прилозима: послије, докле, откле (Maretić ${ }^{3} 1963$ [1899]: 58-59), те даклен, доклен, дотлен, отолен, послијен (Маretić ${ }^{3} 1963$ [1899]: 85). Прилог дӧсле се у Вуковом Рјечнику као и у Речнику САНУ и једнотомном Речнику српскога језика Матице српске (РСЈ 2007) интерпретира као екавизам. У шестотомном Речнику Матице српске (и Матице хрватске) (РМС-МХ 1967-1971; РМС 1973-1976) овај облик се интерпретира као екавизам, али и ијекавски покрајински облик. На ијекавском ареалу налазимо га како у староцрногорским говорима, у говору Загарача (Ћупићи 1997: 81), тако и источнохерцеговачким говорима, у говору Ускока (Станић 1990: 168).

Облике о́вде(на) и о́нде Вук у Рјечнику интерпретира као екавизме. Тако их интерпретира и Речник САНУ. По Р. Маројевићу овдена и ондена су облици са етимолошким $e$ (уп. Маројевић 2005: 833-835). Ти облици се чују у Пиви и Дробњаку: „У извесним говорима јужнога типа налазимо прилоге: овде, онде, али редовно ђе (м. где)". По Вуковићу, у Пиви је редовно óђе / вође и онђе, а у Дробњаку у севернијим селима чује се и овде и онде (Вуковић 1938-1939: 18).

Облик зјенища у стиху:

Што л бијела сунцу на зјенииу! [ГВ 641]

Р. Маројевић интерпретира као књишки ијекавски облик (Маројевић 2005: 75), а облике разлежу и целива, у стиховима:

не разлежу ратнијем клицима? [ГВ 281];

Дође војвода Драшко па се са свијема грли и иелива, [ГВ -1400]

Скида се с коња владика те грли и целива [ГВ -2618]

Улази једно момче к њима, целива [ГВ -2618]

Преклања се улак, целива опет владику у руку, [ГВ -2707],

као неекавизме, тј. као облике са етимолошким $e$. 
У Вуковом Рјечнику облици: зёница, разле́гати и цุели́вати су квалификовани као екавизми, насупрот ијекавским облицима зјёница, разлијѐгати и ијели́вати. Облик зёница (зѐнища) се у Речнику САНУ интерпретира као двојак облик: како екавски тако и ијекавски, а разле́гати и цели́вати у једнотомном Речнику Матице српске као екавизми.

Облици: изеливати, овде, онде, ондена, разлежу, поред облика зеница, јављају се у ијекавским говорима оба типа. Проучаваоци ових говора и Д. Вушовић, као проучавалац Његошевог језика, наведене облике интерпретирају углавном као екавизме и књишке речи (Вушовић 1927: 11; Вушовић 1930: 103-104; Вуковић 1938-1939: 18; Милетић 1940: 251; Пешикан 1965: 105; Ћупић 1977: 29-30).

Префикс не- код неодређених заменица и прилога и глагол обећати нормативни су и у ијекавским говорима, па се на њиховом коментарисању не задржавамо.

4. ИКАВ ИЗМИ. - У „Горском вијенцу” налазимо облике са $u$ код неких глагола VI Стевановићеве врсте чији је однос инфинитивне и презентске основе - $z$ : $u$, и то код глагола оживети и засврбети:

дејателне оживит членове [ГВ 755];

Како су ме длани засврбили: [ГВ 819],

који алтернирају са књижевним облицима, код глагола погладнети и мрети:

вуци су ти љуто погладњели, [ГВ 1795];

Славно мрите, кад мријет морате: [ГВ 2356]

мријет неће док свијета траје: [ГВ 1047].

Облици на $u$ карактеришу како прогресивне тако и староцрногорске ијеавске говоре. Д. Вушовић наводи облике са $u$ у радном глаголском придеву ж.р., у инфинитиву, аористу, презенту и футуру I и објашњава их утицајем радног глаголског придева мушког рода (го̀рила, стрпила се, волила) или императива, што се види по акценту (разу́мисмо ли се, разу́мии ли, разу́мити ce - према разу́ми). За неке облике оставља могућност икавизама, који су дошли из суседних западних говора: рӥћ, рӥћемо, триิш (тријес) (Вушовић 1927: 11). Ј. Вуковић облике тог типа бележи као нетипичне за говор Пиве и Дробњака: „Место старјети [...] редовно чујемо стӓрити, иако у осталим глаголима овога типа имамо (што није особина већине ијекавских говора) сасвим лепо сачуван стари однос инфинитивне и презентске основе $-z: u$ " (Вуковић 1938-1939: 16-17). И М. Пешикан бележи сличну појаву, која је, као по Вушовићу, резултат аналогије према облицима радног глаголског придева. За неке случајеве постоји могућност другачијег обличког утицаја: „Пример 
заповйђет [...] је несигуран, јер ту може бити обличког утицаја глагола вйђет" (Пешикан 1965: 105).

5. ХИПЕРЈЕКАВИЗАМ. - Хиперјекавизам се јавља на месту $\partial ъ$ и 6 в:

видије ли суда од два пића [ГВ 792]

у њих данас овђе видијесмо? [ГВ 113];

слуга брата сунца свијетскога [ГВ 1078].

Глагол видети са је-рефлексом и извршеним јекавским јотовањем налазимо у бројним примерима: у аористу, радном глаголском придеву и инфинитиву:

докле виће у пушку рожину! [ГВ 415]

Владика данило виђе да су се окупили сви [ГВ -509]

Виђесте ли чудо и знамење [ГВ 171]

Ал овога чуда јошт не виђех! [ГВ 159]

Виђех на сан Драшка поповића; [ГВ 1378]

Када вићех витешку невољу, [ГВ 1487]

али ове не виђех несреће: [ГВ 1700]

ја не виђех у једнога момка - [ГВ 1989]

кад виђеше чудо невиђено: [ГВ 1599]

Кад виђели е их погрдише, [ГВ 1610]

мож и данас вићет коштурницу. [ГВ 1226]

кад онамо - имаш што виђети: [ГВ 468]

Ох да ми је очима виђети [ГВ 781]

свуд могаше из зида виђети [ГВ 1539]

И хиперјекавизам има општеијекавски карактер. Иако у опису Његошевог језика каже да: „дуљење кратког b, тј. место једносложног је [...] двосложно uje [...] није особина народног говора у Црној Гори" (Вушовић 1930: 102), Вушовић бележи на новоштокавском ијекавском ареалу гӧрjе (и гӧрије), пријѐпун (и прёпун) (Вушовић 1927: 9). Б. Милетић наводи примере само за облике инфинитива, аориста и радног глаголског придева (ж.р. јд. и м.р. мн.) глагола видети: вйдиёт поред вӥђет, вӥдиеек поред вйђек, вйдиессмо, вйдиесла, вйдиёли (Милетић 1940: 254). Облик видијети потврђен је у црногорским приморским говорима, у говору Паштровића (Јовановић 2005: 226) и Спича (Поповић-Петровић 2009: 26)

6. ПСЕУДОРЕФЛЕКС ЈАТА. - Ову појаву бележимо код именице кандило, која се јавља само у дијалекатској, лексикализованој форми канђело и код именице првијенац:

пред олтаром плакаше канђело, [ГВ 2624]

Ја сам многа зажега канђела [ГВ 2247];

Не дангуби сватски првијенче, [ГВ 1880]. 
У Вуковом Рјечнику облик ка̀нђело се квалификује „у Ц. г.” и упућује на ка̀ндило. У Речнику САНУ облик ка̀нђело се интерпретира као народна и дијалекатска ијекавска форма од ка̀ндило. На ијакавском ареалу каิндило и каิнђело се чује у говору Црмнице (Милетић 1940: 253) и староцрногорским средњокатунским и љешанским говорима (Пешикан 1965: 106), а ка̀нђело и ка̀ндило у источној Херцеговини (Вушовић 1927: 16). Притом, Б. Милетић каже да је форма са јекавским јотовањем „можда под утицајем именице м. $\mathrm{p}$. каิнђел" (Милетић 1940: 253).

У Вуковом Рјечнику облик пр̈вијенаи се квалификује као ијекавска форма и може означавати особу у сватовима, али и у војсци. У једнотомном Речнику Матице српске пӥвијенаи се интерпретира као ијекавски облик именице превенач у значењу „3. а. прва најбоља ракија која потече из казана, првоток; б. први мед, самоток; в. сватовски предводник”. Т. Маретић каже да је код Вука грешком написано пӥвијенаи уместо пр̈вјенаи (Maretić ${ }^{3} 1963$ [1899]: 69). J. Вуковић наводи ову лексему као пример речи са етимологијом која се не може утврдити - не може се поуздано рећи да ли је овде етимолошки јат или e. Он наводи облике првенаи, првјенац и првијенац са различитим значењима (не прецизира којим) и каже да је „ne vodeći mnogo računa o živoj praksi u govoru i u književnom jeziku, novi pravopisni rječnik normirao izgovor prvenac" (Vuković 1974: 80). Д. Ћупић бележи првијенаи у Загарачу са коментаром да је: „пйвенаи назив за први литар ракије из казана (при дестилацији) а пр̈вииенаи име свата са одређеном функцијом" (Ћупић 1977: 30).

7. ДЕФОНОЛОГИЗАЦИЈА ДУГОГ ЈАТА. - Дефонологизација $\bar{z}$ у префиксалној морфеми $n p \bar{b}$ јавља се само у два примера, код лексеме престол:

престол сруши а тартар уздрма. [ГВ 236]

који сьдиш на престол небесни [ГВ 743]

и алтернира са књижевним формама, код именице пријекор и прилога упријекрст.

да га свијет мори пријекором, [ГВ 1052];

упријекрст ка треба метнули? [ГВ 2439].

Облик пре́сто̄ / престол Вук у Рјечнику интерпретира као екавизам. И у једнотомном Речнику Матице српске облик пре́сто̄ има исту квалификацију. Р. Маројевић $е$ у овој речи интерпретира као дефонолозацију дугог јата (Маројевић 2005: 80, 811-812), која карактерише цео ијекавски ареал. У опису црмничкога говора Б. Милетић бележи „именице (које) имају или искључиво

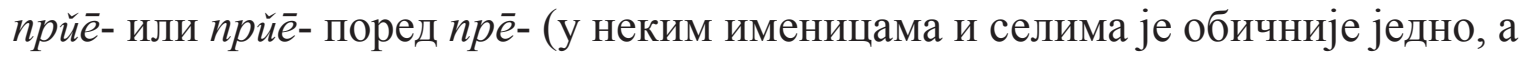
у другима друго", при чему не бележи именицу престол (Милетић 1940: 245). Говорећи о именицама са префиксом прё-, он наводи: „Ова три облика пре- 


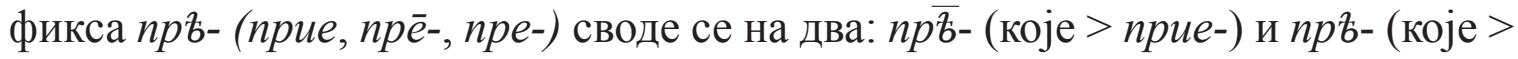
npe-); $n p \bar{e}$ - је постало секундарним дуљењем од пре-" (Милетић 1940: 246-247). За староцрногорске љешанске и катунске говоре М. Пешикан каже: „Префикс $n p \check{-}-[. .$.$] кад одговара дугом слогу [...] у речима старијег постанка он редовно$ гласи $n p u^{j} e-[\ldots]$ У новијим, аналошким образовањима или унесеним речима чује се $п р \bar{e}-"$ (Пешикан 1965: 105). Говорећи о екавском рефлексу јата у говору Бјелопавлића, Д. Ћупић наводи облике са пръ- са дугим јатом: пре́нос, пре́воз итд., али и неке облике који имају само двосложни ије-рефлекс: прииѐклад, прииѐтит, прииѐћ (Ћупић 1977: 27). У говору источне Херцеговине Д. Вушовић бележи облике: пре́коран / пријѐкоран, пре́лаз / пријѐлаз, пре́кор, пре́лом (Вушовић 1927: 10). У говору Пиве и Дробњака Ј. Вуковић уз именице са кратким јатом (зеница и цеста) наводи и именицу са дугим јатом - пренос. За све ове облике каже да су „обични примери где место старог $z$ налазимо $e^{\prime}$ и да су „општије природе у говорима јужнога типа [...] што је дошло мешањем дијалеката, или утицајем књижевног језика” (Вуковић 1938-1939: 18).

8. ГРУ ПЕ Ђ $>\boldsymbol{J E}+\boldsymbol{J}, \boldsymbol{\boldsymbol { b }}$. - Одступања од појаве $\boldsymbol{b}>\boldsymbol{u}+o, j$, љ налазимо у облику бјељега и у облицима компаратива и суперлатива прилога прије: nређе, приђе, најприђе.

Од лексема са основом (-)бълъ- бележимо само лексему биљега у дијалекатској форми - са секвенцом -је- испред љ:

само да сте цару на бјељьегу [ГВ 1101],

насупрот књижевној форми:

обиъежја од турскога уха [ГВ 2723].

У Вуковом Рјечнику облик бјѐљег се квалификује „у Ц. г.” и упућује на облике бйљег и бйљега. И у Речнику САНУ бјѐљег и бјѐлег су покрајински ијекавски облици. У неким дијалектима староцрногорског типа налазимо: бјелёг или бљелёг, а чује се и биљёг, само ретко (Стевановић 1933-1934: 24), бљелёг, бјелёг, бљёлега, бјёлега што је обичније од биљёг, биљёга (Милетић 1940: 250), бѝљег / бјѐљег / бјѐлег (Ћупић 1977: 28). Тако је и у говору Пиве и Дробњаке: „Нередовна је замена $b$ са $u$ испред новога $љ$ и $\hbar$ : бйљег” (Вуковић 1938-1939: 17).

Код компаратива и суперлатива прилога прије фреквентније су дијалекатске форме са гласом $\hbar$ :

пређе рока дошла ти је жњетва! [ГВ 653];

Приђе си им с коца утекао - [ГВ 543]

свакога ми узе приће рока, [ГВ 978]

приђе зоре на поље Крстачко: [ГВ 1065]

није вино пошто приће бјеше, [ГВ 1135] 
да ђавола приђе у њих видиш — [ГВ 1728]

пред Пророка да приђе изађеш, [ГВ 1786]

но ће приђе море ослачати! [ГВ 1831]

приђе но смо легли и заспали. [ГВ 2243];

најприђе ти Божић честитамо, [ГВ 2587],

које алтернирају са формама с књижевним рефлексом дугог јата:

Хитали смо да пријед дођемо, [ГВ 327]

ти издао пријед и послијед, [ГВ 381]

од Косова, а ни пријед њега! [ГВ 394]

и кликује човјек као пријед. [ГВ 465].

Облике прёђе и прӥђе Вук у Рјечнику упућује на прйје при чему прӥђе квалификује „по југоз. кр.”. За облике прије, приђе и пређе Т. Маретић каже да се налазе у ,јужном говору" (Maretić ${ }^{3} 1963$ [1899]: 61, 103). Б. Милетић разматра ову појаву говорећи о рефлексу $b$ испред $\hbar:$,За $u$ испред $ち$ забележио сам само прйђе [...] нӓ(j)nриђе [...] пӧприђе [...], које је такође могло доћи са стране или бити начињено према прӥ $(j) e$ ” и додаје у фусноти: „Од прњдје очекивали бисмо у овом говору прёђе, које се одиста чује, иако је прӥђе обичније, уп. pъдје > pёђе" (Милетић 1940: 250). На њега се надовезује М. Пешикан: „Што се тиче примера прйђе и сл. (употребљава се и прӥंе(д) и прёђе) биће у праву Мил[етић] [...] да је то аналошко образовање преме прије, а не фонетска промена е̌ у $u$. Заправо ће пређе бити нормалан облички компаратив од прйंed (са секундарним $\partial$ ). Пошто и само прй'ед има компаративно значење, лако је могло доћи до контаминације” (Пешикан 1965: 105). И Д. Ћупић бележи у Бјелопавлићима прӥие(д) и прёђе (Һупић 1977: 101).

9. ЗАКљУЧАК. - Анализа рефлекса јата и појава у вези с јатом у оквиру теме о фонетским дијалектизмима у критичком издању „Горског вијенца" Р. Маројевића показује следеће дијалекатске појаве: једносложни рефлекс дугог јата, рефлекс $e$ после $p$ и кратког јата, екавизми, икавизми, хиперјекавизам, псеудорефлекс јата, дефонологизација дугог јата, рефлекс је испред $j$ и $љ$. Са дијалектолошког становишта, облици са датим партикулама су општеијекавског карактера, потврђени у оба типа ијекавских говора: како староцрногорском тако и источнохерцеговачком.

Облици са дијалекатским рефлексом алтернирају са формама са књижевним рефлексом. Те форме, које у савременом српском језику имају књижевни статус, такав статус су имале и у Његошево време.

Употреба дијалекатских облика карактерише и версолошка и, на одређени начин, и стилска функција. Вокал попуњава силабичку структуру првог или другог полустиха, што је основни разлог употребе одговарајућих гласова у песничком делу у стиху. 


\section{ИЗВОРИ И ЛИТЕРАТУРА}

Вуковић 1938-1939: Ј. Вуковић, Говор Пиве и Дробњака, Јужнословенски филолог, XVII, 1-113.

Vuković 1974: J. Vuković, Istorija srpskohrvatskog jezika, dio I, Uvod i fonetika, Beograd: Naučna knjiga.

Вушовић 1927: Д. Вушовић, Диалект источне Херцеговине, Српски дијалектолошки зборник, III, 1-70.

Вушовић 1930: Д. Вушовић, Прилози проучавању Његошева језика, Јужнословенски филолог, IX, 93-196.

Драгићевић 1959: Петар Петровић Његош, Горски вијенаи, [Предговор Јагош Јовановић. Приредио за штампу и прилоге написао Ристо Ј. Драгићевић. Коментар и речник Милан Решетар], Титоград.

Јовановић 2005: М. Јовановић, Говор Паштровића, Подгорица: Универзитет Црне Горе.

Караџић ${ }^{4} 1935$ [1852]: В. Караџић, Српски рјечник, Београд.

Maretić ${ }^{3} 1963$ [1899]: T. Maretić, Gramatika hrvatskoga ili srpskoga književnog jezika, Zagreb: Matica hrvatska.

Маројевић 1997: Р. Маројевић, Горски вијенац (1847-1997): У сусрет критичком издању, Ријеч, 2, Никшић, 41-63.

Маројевић 2005: Петар II Петровић Његош, Горски вијенаи. Критичко издање. Текстологија. Редакција и коментар Радмила Маројевића, Подгорица: ЦИД.

Милетић 1940: Б. Милетић, Црмнички говор, Српски дијалектолошки зборник, IX, 209-663.

Николић 1991: М. Николић. Говори Србијанског Полимља, Српски дијалектолошки зборник, XXXVII, 1-548.

Његош 1847: Горскій віенацъ историческо событіє при свршетку XVII виека. Сочиненіє П. П. Н. Владыке чрногоскога, Беч.

Пецо 1989: A. Peco, Pregled srpskohrvatskih dijalekata, Beograd: Naučna knjiga.

Пешикан 1965: М. Пешикан, Староцрногорски средњокатунски и љешански говори, Српски дијалектолошки зборник, XV.

Поповић/Петровић 2009: М. Поповић и Д. Петровић, О говору Спича (грађа), Српски дијалектолошки зборник, LVI, 1-275.

Решетар 1890: Горски вијенац владике црногорскога Петра Петровића Његоша. Увод и коментар написао Милан Решетар, Загреб. 
Решетар 101940: Горски вијенаи владике црногорскога Петра Петровића Његоша. Десето издање с уводом и коментаром Милана Решетара, Београд.

PMC 1973-1976: Речник српскохрватскога књижевног језика, IV-VI, Нови Сад: Матица српска.

PMC-MX 1967-1971: Речник српскохрватскога књижевног језика, I-IV, Нови Сад: Матица српска, Загреб: Матица хрватска.

РСАНУ 1959-2017: Речник српскохрватског књижевног и народног језика, $\mathrm{I}-\mathrm{XX}$, Београд: Српска академија наука и уметности.

PCJ 2007: Речник српскога језика, Нови Сад, Матица српска.

Станић 1974: М. Станић, Ускочки говор I, Српски дијалектолошки зборник, XX.

Станић 1990: М. Станић, Ускочки речник I, Београд: Научна књига.

Стевановић 1933-1934: М. Стевановић, Источноцрногорски дијалекат, Јужнословенски филолог, XIII, Београд, 1-128 + Карта источноцрногорског говора.

Ћупић 1977: Д. Ћупић, Говор Бјелопавлића, Српски дијалектолошки зборник, XXIII.

Ћупићи 1997: Д. Ћупић и Ж. Ћупић, Речник говора Загарача, Српски дијалектолошки зборник, XLIV.

\section{DIALECTAL YAT-RELATED OCCURRENCES IN RADMILO MAROJEVIĆ'S CRITICAL EDITION OF THE MOUNTAIN WREATH}

\section{Summary}

The paper discusses the yat-related dialectal occurrences in The Mountain Wreath within the field of phonetic dialecticisms in Njegoš's epic. The given occurrences are viewed from the standpoint of their standard language status, distribution in ijekavian vernacular speeches and function in the poetic text. The analysis demonstrates these dialectal occurrences: a monosyllabic reflex of the long yat, the e reflex after $r$ and the short yat, ekavisms, ikavisms, hyperjekavism, pseudoreflex of the yat, dephonologisation of the long yat, je reflex in front of $j$ and $l j$. From the dialectological standpoint, the given dialectal occurrences have a general ijekavian character, confirmed in both types of ijekavian speeches: Old Montenegrin and Eastern Herzegovinian. The forms with a dialectal reflex alternate with the forms that have a standard reflex. Those forms, which have a standard status in contemporary Serbian, had the same status in Njegoš's time as well. The use of dialectal forms is also characterised by a versological and, in a way, a stylistic function. The vowel fills in the syllabic structure of the first or second hemistich, which is the main reason for the use of the corresponding sounds in the verse work. 